\title{
HUBUNGAN USIA MENARCHE DENGAN OBESITAS PADA REMAJA PUTRI DI SMA THERESIANA 1 SEMARANG
}

\author{
Silvia Agus Widyaningtyas, Apoina Kartini: ${ }^{*}$ \\ Program Studi Ilmu Gizi Fakultas Kedokteran Universitas Diponegoro \\ Jl.Dr.Sutomo No.14, Semarang, Telp (024) 8453708, Email : gizifk@ undip.ac.id
}

\begin{abstract}
Background: Obesity is one of world health problem that caused by excessive of body fat. Body fat storage associated with sexual maturation, which is marked by having first menstruation (menarche) in adolescent girl. Body fat will increase after having first menstruation, if it not managed properly it would leads to obesity. This study is aimed to identify the correlation between menarcheal age and obesity which occur among adolescent girl in high school of Theresiana 1 Semarang.

Method: The design of this study was cross sectional. The amount of this sample was 71, subject chosen by using stratified random sampling of all student grade X and XI. Nutrition status where determined by z-score of BMI-forage. It supported with body fat percentage, that measured by Bioelectrical Impedance Analysis (BIA). Subject and family menarcheal age data were collected by questionnaire, food intake (energy, carbohydrate, protein and fat) were collected by semi quantitative food frequency and physical activity data was collected by 3 day physical activity questionnaire. The Data was analyzed by Rank Spearman, Pearson Product Moment and multiple linier regression test.

Result: Number of 14,1\% subjects were obesity. Mean of subject menarcheal age was 12,1 1,3 y and 2,8\% was categorized as early menarche $(<10 y)$. This study showed that there was no association menarcheal age $(r=-0,151$; $p=0,209)$, energy intake ( $r=-0,009 ; p=0,942)$, protein intake $(r=0,113 ; p=0,35)$ and fat intake $(r=-0,024 ; p=0,844)$ with obesity. However there was association between physical activity $(r=-0,236 ; p=0,031)$ with obesity and also, there was association between family menarcheal age with subject menarcheal age $(r=0,445 ; p=0,000)$. The most relating factor towards obesity was physical activity $(p=0,040)$.

Conclusion: There was no association between menarcheal age with obesity, however there was association between physical activity with obesity by the BMI-for-age parameter.
\end{abstract}

Key word: Obesity; body fat percentage; menarcheal age; adolescent girl; physical activity; food intake

\begin{abstract}
ABSTRAK
Latar belakang: Obesitas merupakan salah satu masalah kesehatan dunia yang terjadi akibat simpanan lemak yang berlebih. Simpanan lemak berkaitan dengan kematangan seksual yang ditandai dengan munculnya menstruasi pertama (menarche) pada remaja putri. Remaja akan mengalami peningkatan komposisi lemak tubuh setelah mengalami menstruasi, apabila tidak dikendalikan dengan benar dapat membawa pada kejadian obesitas. Penelitian ini bertujuan untuk mengkaji hubungan usia menarche dengan obesitas pada remaja putri di SMA Theresiana 1 Semarang.

Metode: Rancangan penelitian cross sectional, sampel berjumlah 71 dipilih secara stratified random sampling dari seluruh kelas X dan XI. Status gizi didasarkan nilai z-score IMT/U dan ditunjang dengan pengukuran persen lemak tubuh menggunakan Bioelectrical Impedance Analysis (BIA). Data usia menarche sampel dan keluarga didapatkan dari kuesioner, data asupan makan (energi, karbohidrat, protein dan lemak) didapatkan dari kuesioner semi quantitative food frequency dan aktivitas fisik didapatkan dari formulir recall aktivitas fisik selama 3 hari. Analisis data menggunakan Rank Spearman, Pearson Product Moment dan regresi linier ganda.

Hasil: Sebanyak 14,1\% subyek mengalami obesitas. Rata-rata usia menarche subyek 12,1 1, 3 tahun dan sebanyak $2,8 \%$ berkategori dini ( 10 tahun). Tidak terdapat hubungan usia menarche $(r=-0,151 ; p=0,209)$, asupan energi $(r=-0,009 ; p=0,942)$, asupan protein $(r=0,113 ; p=0,35)$ dan asupan lemak $(r=-0,024 ; p=0,844)$ dengan obesitas. Namun terdapat hubungan antara aktifitas fisik dengan obesitas $(r=-0,236 ; p=0,031)$ dan terdapat hubungan usia menache keluarga dengan usia menarche subyek $(r=0,445 ; p=0,000)$. Faktor yang paling berhubungan dengan obesitas adalah aktifitas fisik $(p=0,040)$.

Simpulan: Tidak terdapat hubungan antara usia menarche dengan obesitas pada remaja, namun pada penelitian ini menunjukkan terdapat hubungan antara aktivitas fisik dengan obesitas melalui parameter IMT/U.
\end{abstract}

Kata Kunci: Obesitas; usia menarche; remaja putri; aktivitas fisik; asupan makan

\footnotetext{
${ }^{*}$ Penulis Penanggungjawab
} 


\section{PENDAHULUAN}

Obesitas merupakan masalah kesehatan dunia dengan jumlah prevalensi yang selalu meningkat setiap tahun, baik di negara maju maupun berkembang. ${ }^{1}$ Obesitas merupakan salah satu penyebab terbesar kematian di dunia karena merupakan faktor risiko terjadinya penyakit degeneratif seperti Diabetes Melitus Tipe 2, Hipertensi, Penyakit Jantung Koroner dan beberapa penyakit Kanker. ${ }^{2,3}$

Obesitas terjadi akibat ketidakseimbangan antara asupan dengan pengeluaran energi, hingga berdampak pada peningkatan berat badan yang berlebih. ${ }^{1,2}$ Masalah kesehatan akibat obesitas tidak hanya berkaitan dengan akumulasi lemak yang berlebih, namun juga berkaitan dengan distribusi lemak dalam tubuh. ${ }^{4}$ Distribusi lemak pada abdominal atau viseral dihubungkan dengan penyakit degeneratif seperti penyakit jantung dan sindroma metabolik., ${ }^{3,4}$

Simpanan lemak sangat dibutuhkan untuk perkembangan dan pertumbuhan, salah satunya adalah untuk kematangan seksual. Lemak merupakan salah satu zat gizi yang diperlukan dalam pembentukkan hormon seksual seperti estrogen, androgen dan progesteron. ${ }^{4,5}$ Kematangan seksual pada perempuan ditandai dengan munculnya menstruasi pertama (menarche). Menarche muncul pada usia 10-16 tahun pada masa pubertas dan sangat dipengaruhi oleh status gizi. ${ }^{6}$ Berdasarkan penelitian yang dilakukan oleh Rahmawati dan Hastuti di Yogyakarta menunjukkan bahwa usia menarche remaja putri pada tahun 2005 mengalami percepatan dibandingkan pada tahun 1982 yaitu dari 13 tahun menjadi 11 tahun. $^{7}$

Perempuan yang telah mengalami menarche akan mengalami perubahan komposisi tubuh hingga usia remaja terutama komposisi lemak. $^{6}$ Komposisi lemak tubuh perempuan dua kali lebih besar dari laki-laki, dimana terjadi peningkatan dari 16-18\% pada usia pra-remaja menjadi $23 \%$ pada usia remaja. ${ }^{8,9}$ Peningkatan komposisi lemak tubuh ditambah dengan simpanan lemak yang berlebih pada usia sebelum menarche apabila tidak dikendalikan dengan benar akan membawa pada kejadian obesitas remaja. Hal ini ditunjang dengan penelitian oleh Laitien di Finlandia Utara yang menunjukkan bahwa proporsi overweight dan obesitas dewasa lebih tinggi pada wanita dengan usia menarche yang lebih dini yaitu $\leq 11$ tahun..$^{10}$ Namun, pada penelitian di Iran oleh Berenjy tidak menunjukkan hubungan antara usia menarche dengan kejadian obesitas pada remaja putri. ${ }^{11}$

Di Indonesia, menurut data RISKESDAS Nasional tahun 2007 prevalensi penderita obesitas pada usia remaja adalah $1,1 \%{ }^{12}$ Penderita obesitas lebih banyak ditemui pada remaja putri, di daerah perkotaan dengan status sosial ekonomi menengah keatas. ${ }^{12,13} \mathrm{Hal}$ ini ditunjang dengan penelitian oleh Madiyah di DIY yang menunjukkan bahwa prevalensi obesitas remaja lebih tinggi di kota besar yaitu sebanyak 7,9\%, dibandingkan pada daerah perdesaan sebanyak $2 \% .{ }^{14}$

Jawa Tengah merupakan salah satu provinsi dengan jumlah prevalensi obesitas remaja yang cukup tinggi pada tahun 2007 sebanyak 9,0\% dan pada tahun 2010 prevalensi gizi lebih remaja di Jawa Tengah 0,7\%. ${ }^{14,15}$ Kota Semarang merupakan ibu kota Provinsi Jawa Tengah dengan prevalesi obesitas yang cukup tinggi yaitu 9,6\% pada tahun 2007. ${ }^{15}$

Berdasarkan latar belakang diatas peneliti tertarik untuk mengkaji apakah usia menarche berhubungan dengan kejadian obesitas remaja. Serta menganalisis usia menarche keluarga, aktivitas fisik dan asupan makan pada siswi di SMA Theresiana 1 Semarang.

\section{METODE PENELITIAN}

Penelitian ini dilakukan di SMA Theresiana 1 Semarang pada bulan Agustus 2012. Ruang lingkup keilmuan penelitian ini adalah Gizi Masyarakat, dan merupakan penelitian deskriptif analitik dengan rancangan penelitian crosssectional. Populasi terjangkau pada penelitian ini adalah siswi kelas X dan XI di SMA Theresiana 1 Semarang. Pemilihan subyek dilakukan secara stratified random sampling hingga mencapai jumlah sampel minimal yaitu sebanyak 71 . Subyek yang diambil telah memenuhi kriteria inklusi, antara lain bersedia mengisi inform consent, sudah mengalami menstruasi, tidak sedang mengalami amenorea primer dan mendapatkan terapi hormonal.

Usia menarche merupakan variabel bebas dalam penelitian ini, diperoleh dari pengisian kuisoner riwayat usia menarche kemudian dikelompokkan menjadi tiga yaitu, dini $(<10$ tahun), normal (10-14 tahun) dan lambat ( $>14$ tahun). ${ }^{16}$ Variabel terikat pada penelitian ini adalah status gizi, menggunakan parameter nilai zscore IMT/U melalui program WHO Anthro Plus 2007 dan dikelompokkan menjadi dua yaitu obesitas $(>+2 \mathrm{SD})$ dan non obesitas $(\leq+2 \mathrm{SD})$. Variabel ini ditunjang menggunakan persen lemak 
tubuh yang diukur menggunakan alat Bioelectrical Impedance Analysis (BIA) dan dikelompokkan menjadi tiga yaitu, rendah $(<20 \%)$, normal $(20 \%$ $30 \%)$ dan tinggi (>30\%).

Sedangkan untuk variabel perancu terdiri dari genetik, aktivitas fisik dan asupan makanan. Genetik merupakan usia menarche keluarga sekandung yang diperoleh dari pengisian kuisoner. Sama halnya dengan usia menarche genetik dikelompokkan menjadi tiga yaitu dini, normal dan lambat.

Aktivitas fisik diperoleh dari hasil pengisian formulir recall aktivitas fisik selama tiga hari yang berisi intensitas dan jenis aktivitas fisik. Kemudian dari hasil recall, jenis aktivitas fisik dikonversikan kedalam satuan MET (Metabolic Equivalent Task) kemudian dijumlahkan dan dirata-rata. Dari data tersebut kemudian dikelompokkan menjadi ringan ( $<3$ MET), sedang (3-5,9 MET) dan berat $\quad\left(\geq 6\right.$ MET). ${ }^{17}$

Asupan makanan merupakan data yang didapatkan dari banyaknya makanan yang terasup terdiri dari beberapa zat gizi seperti energi, karbohidrat, lemak dan protein yang dikonsumsi tiap hari dengan metode Food Frequency. Data asupan yang diperoleh dikonversikan ke dalam satuan kalori untuk energi, gram untuk, lemak dan protein. Kemudian dihitung dengan menggunakan program nutrisurvey dan dibandingkan dengan AKG tahun 2004 untuk remaja putri yang dinyatakan dalam persen dan dikelompokkan menjadi tiga yaitu asupan makan berlebih $(\geq 120 \%$ AKG), normal (90\%-119\% AKG) dan kurang ( $\leq$ $89 \%$ AKG). ${ }^{18}$

Analisis data meliputi analisis univariat, bivariat dan multivariat. Sebelum menganalisis adanya hubungan, data diuji distribusinya menggunakan uji Kolmogorov-Smirnov. Data yang berdistribusi tidak normal (usia menarche, usia menarche keluarga dan aktivitas fisik) diuji menggunakan uji korelasi Rank Spearman. Data yang berdistribusi normal (obesitas, tingkat kecukupan energi, protein dan lemak) diuji menggunakan korelasi Pearson product moment. Analisis multivariat dilakukan untuk mengetahui variabel yang paling berhubungan menggunakan uji regresi linear ganda.

\section{HASIL PENELITIAN}

\section{A. Analisis Univariat}

Umur subyek dalam penelitian ini berkisar antara 15-17 tahun. Distribusi frekuensi menurut umur dapat dilihat pada tabel dibawah ini.

Tabel 1. Distribusi Frekuensi Menurut Umur

\begin{tabular}{lcc}
\hline Umur & Frekuensi (n) & Persen $(\%)$ \\
\hline 15 tahun & 21 & 29,6 \\
16 tahun & 25 & 35,2 \\
17 tahun & 25 & 35,2 \\
\hline Total & 71 & 100 \\
\hline
\end{tabular}

Berdasarkan Tabel 1 diatas diketahui bahwa frekuensi subyek pada usia 15 tahun merupakan frekuensi terkecil yaitu sebanyak 21 subyek $(29,6 \%)$. Dari hasil pengukuran berat badan didapatkan bahwa rata - rata remaja memiliki berat badan $55,2 \pm 11,6 \mathrm{~kg}$ dengan nilai maksimum 82,7 $\mathrm{kg}$ dan nilai minimum $36,9 \mathrm{~kg}$. Rata - rata tinggi badan subyek adalah $155,5 \pm 5,8 \mathrm{~cm}$ dengan nilai maksimum 170,5 cm dan nilai minimum $139,5 \mathrm{~cm}$.

Pada penelitian ini, terdapat beberapa variabel yang terdiri dari status gizi, persen lemak tubuh, usia menarche subyek, usia menarche keluarga, aktfitas fisik dan asupan makan (energi, protein dan lemak).

\section{Usia Menarche subyek dan keluarga}

Usia menarche subyek berkisar dari 8

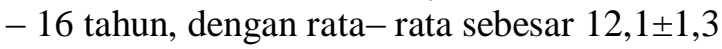

tahun. Sedangkan usia menarche keluarga berkisar dari usia 10 - 16 tahun, dengan rata rata $12,4 \pm 1,3$ tahun. Usia menarche subyek dengan kategori normal (10-14 tahun) merupakan kategori dengan frekuensi terbesar yaitu sebanyak 67 subyek $(94,4 \%)$. Pada usia menarche keluarga menunjukkan bahwa terbesar terdapat pada kategori normal yaitu sebanyak 66 subyek (93\%). Hal ini menunjukkan bahwa usia menarche subyek dan keluarga sebagian besar berkategori normal yaitu berkisar pada usia 10 - 14 tahun.

2. Status Gizi

Berdasarkan parameter nilai z-score IMT/U didapatkan rata - rata sebanyak 0,34 $\pm 1,34$ SD, dengan nilai maksimum 3,07 SD dan nilai minimum -2,68 SD. Subyek yang mengalami obesitas sebanyak 10 subyek $(14,1 \%)$, sedangkan subyek non obesitas 
menunjukkan jumlah yang lebih besar yaitu sebanyak 61 subyek $(85,9 \%)$. Dari data tersebut menunjukkan bahwa sebagian besar subyek tidak mengalami obesitas.

\section{Persen Lemak Tubuh}

Persen lemak tubuh subyek berkisar dari $15,3 \%$ - 40,3\% dengan rata - rata sebesar $27,2 \pm 6,8 \%$. Dari hasil pengumpulan data persen lemak tubuh, sebanyak $29 \%$ subyek berkategori normal,13\% persen subyek berkategori rendah dan sebanyak $29 \%$ subyek berkategori lebih. Dari data tersebut menunjukkan bahwa persen lemak tubuh subyek berkategori normal sama besar dengan subyek berkategori lebih.

\section{Aktivitas Fisik}

Aktivitas fisik subyek berkisar dari 1,3 - 3,12 MET/hari dengan rata- rata $1,7 \pm 0,38$ MET/hari. Dari hasil pengumpulan data didapatkan bahwa tidak terdapat subyek dengan tingkat aktivitas fisik berat, sebanyak 2 subyek $(2,8 \%)$ subyek memiliki tingkat aktivitas fisik sedang, dan sebanyak 69 subyek $(97,2 \%)$ memiliki tingkat aktivitas fisik ringan. Dapat disimpulkan bahwa sebagian besar subyek memiliki tingkat aktivitas fisik ringan.

\section{Asupan Makan}

Asupan energi subyek berkisar dari 874,2 - 4264,0 kkal/hari dengan rata - rata asupan sebesar 2260,6 $\pm 696,6 \mathrm{kkal} / \mathrm{hari}$. Sebagian besar subyek memiliki tingkat kecukupan yang kurang $(\leq 89 \% \quad \mathrm{AKG})$ sebanyak 28 subyek $(39,4 \%)$. Asupan protein subyek berkisar dari 32,5 - $184 \mathrm{~g} /$ hari dengan rata - rata asupan sebesar 89,7 $\pm 35,7$ g/hari. Sebagian besar subyek memiliki tingkat kecukupan berlebih ( $\geq 120 \%$ AKG), yaitu sebanyak 53 subyek (74,6\%).

Asupan lemak subyek berkisar dari 39,7 - 89,1g/hari dengan rata - rata asupan sebesar 111,3 $\pm 42,4 \mathrm{~g} /$ hari. Sebagian besar subyek memiliki tingkat kecukupan kurang ( $\leq$ $89 \%$ AKG), yaitu sebanyak 59 subyek $(83,1 \%)$. Distribusi frekuensi asupan gizi subyek dapat dilihat pada Tabel 2 .

Tabel 2. Distribusi Frekuensi Variabel penelitian

\begin{tabular}{|c|c|c|c|}
\hline Variabel & Persen (\%) & Median & Rerata \pm SD \\
\hline \multicolumn{4}{|l|}{ Status Gizi } \\
\hline Non Obesitas & 85,9 & \multirow{2}{*}{0,49} & \multirow{2}{*}{$0,34 \pm 1,36$} \\
\hline Obesitas & 14,1 & & \\
\hline \multicolumn{4}{|c|}{ Persen Lemak Tubuh } \\
\hline Rendah & 13 & \multirow{3}{*}{27,3} & \multirow{3}{*}{$27,2 \pm 6,8$} \\
\hline Normal & 29 & & \\
\hline Tinggi & 29 & & \\
\hline \multicolumn{4}{|l|}{ Usia Menarche } \\
\hline Dini & 2,8 & \multirow{3}{*}{12,0} & \multirow{3}{*}{$12,14 \pm 1,3$} \\
\hline Normal & 94,4 & & \\
\hline Lambat & 2,8 & & \\
\hline \multicolumn{4}{|c|}{ Usia Menarche Keluarga } \\
\hline Dini & 0 & \multirow{3}{*}{12,0} & \multirow{3}{*}{$12,42 \pm 1,2$} \\
\hline Normal & 93 & & \\
\hline Lambat & 7 & & \\
\hline \multicolumn{4}{|l|}{ Aktivitas fisik } \\
\hline Ringan & 97,2 & \multirow{3}{*}{1,54} & \multirow{3}{*}{$1,7 \pm 0,38$} \\
\hline Sedang & 2,8 & & \\
\hline Berat & 0 & & \\
\hline \multicolumn{4}{|l|}{ Asupan Energi } \\
\hline Kurang & 39,4 & \multirow{3}{*}{2241,2} & \multirow{3}{*}{$2260 \pm 69,6$} \\
\hline Normal & 38 & & \\
\hline Lebih & 22,5 & & \\
\hline \multicolumn{4}{|l|}{ Asupan Protein } \\
\hline Kurang & 8,5 & \multirow{3}{*}{82,0} & \multirow{3}{*}{$89,74 \pm 35,9$} \\
\hline Normal & 16,9 & & \\
\hline Lebih & 74,6 & & \\
\hline
\end{tabular}




\begin{tabular}{lccc}
\hline Asupan Lemak & & & \\
Kurang & 83,1 & 113,0 & $111,26 \pm 4,2$ \\
Normal & 12,7 & & \\
Lebih & 4,2 & & \\
\hline
\end{tabular}

\section{B. Analisis Bivariat}

Pada analisis bivariat, dilakukan analisis hubungan antara obesitas dengan usia menarche subyek, aktivitas fisik, asupan energi, protein dan lemak. Selain itu dianalisis hubungan usia menarche keluarga terhadap usia menarche subyek yang berpengaruh tidak langsung terhadap status gizi.

Dari hasil analisis uji korelasi Pearson's Product Moment, didapatkan bahwa tidak terdapat korelasi antara status gizi melalui parameter IMT/U dengan asupan energi $(\mathrm{r}=-0,009 ; p=0,942)$, asupan protein $(\mathrm{r}=0,113 ; p=0,35)$ dan asupan lemak $(\mathrm{r}=-$ $0,024 ; p=0,844)$. Pada analisis uji korelasi Rank Spearman didapatkan bahwa tidak terdapat korelasi antara status gizi dengan usia menarche subyek $(\mathrm{r}=-0,151 ; p=0,209)$. Namun, terdapat hubungan antara obesitas dengan aktivitas fisik $(\mathrm{r}=-0,236 ; p=0,031)$, dimana terdapat korelasi negatif antara aktivitas fisik dengan status gizi.

Tabel 3. Analisis Bivariat Beberapa Variabel dengan Status Gizi

\begin{tabular}{lcc}
\hline Variabel & $\boldsymbol{p}$ & $\mathbf{R}$ \\
\hline Usia menarche $^{\mathrm{a}}$ & 0,209 & $-0,151$ \\
Aktivitas fisik $^{\mathrm{a}}$ & $0,031^{*}$ & $-0,256$ \\
Asupan Energi $^{\mathrm{b}}$ & 0,942 & $-0,090$ \\
Asupan Protein $^{\mathrm{b}}$ & 0,350 & 0,113 \\
Asupan Lemak $^{\mathrm{b}}$ & 0,844 & $-0,240$ \\
\hline
\end{tabular}

${ }^{a}$ Uji Korelasi Rank Spearman ${ }^{b}$ Uji Korelasi Pearson

*Bermakna secara statistik $(p<0,05)$

Sedangkan pada analisis bivariat menggunakan korelasi Rank Spearman antara usia menarche keluarga dengan usia menarche subyek didapatkan bahwa terdapat hubungan yang bermakna $(\mathrm{r}=0,445 ; p=0,00)$. Dimana pada hasil analisis tersebut menunjukkan bahwa usia menarche keluarga berkorelasi positif dengan usia menarche subyek.

\section{Analisis Multivariat}

Analisis multivariat menggunakan uji regresi linier ganda untuk melihat variabel yang paling berhubungan dengan status gizi. Berdasarkan hasil analisis didapatkan bahwa variabel aktivitas fisik dan usia menarche masuk kedalam model analisis multivariat $(p<0,25)$. Pada uji regresi linier kedua variabel tersebut menunjukkan bahwa aktivitas fisik merupakan variabel yang paling berhubungan dengan status gizi. Hasil analisis dapat dilihat pada Tabel 6 dibawah ini.

Tabel 5. Analisis Multivariat

\begin{tabular}{|c|c|c|c|}
\hline Model & $\frac{\text { Koefisien }}{\text { B }}$ & $P$ & Adjusted $\mathrm{R}^{2}$ \\
\hline Konstanta & 3,370 & 0,032 & \\
\hline Aktivitas Fisik & $-0,853$ & 0,040 & 0,055 \\
\hline Usia Menarche & $-0,129$ & 0,277 & \\
\hline
\end{tabular}

Koefisien determinasi (adjusted $\mathrm{R}^{2}$ ) diperoleh sebesar 5,5\% sedangkan 94,5\% dijelaskan oleh variabel-variabel yang lain yang tidak diteliti. Persamaan garis linier yang dapat diperoleh yaitu status gizi $=3,370-$
$(0,853$ x Aktivitas fisik $)-(0,129$ x Usia Menarche). Dapat diinterpretasikan terjadi hubungan negatif antara aktivitas fisik dan usia menarche dengan status gizi melalui parameter z-score IMT/U. 


\section{PEMBAHASAN}

Pada penelitian ini tidak terdapat hubungan yang bermakna secara statistik antara usia menarche dengan obesitas melalui parameter IMT/U. Hal ini tidak sesuai dengan penelitian yang dilakukan oleh Kim Ji-Yeong di Korea menunjukkan bahwa remaja yang mengalami menarche dini memiliki berat badan dan tinggi badan yang lebih tinggi dibandingkan remaja yang mengalami menarche lambat. ${ }^{19}$ Data yang didapatkan pada penelitian ini menunjukkan bahwa rata-rata usia menarche subyek $12,1 \pm 1,3$ tahun, dan sebagian besar usia menarche berkategori normal (10-14 tahun). Penelitian ini sejalan dengan penelitian sebelumya di Iran, yang menunjukkan bahwa tidak terdapat hubungan antara usia menarche dengan obesitas pada remaja. ${ }^{11}$ Selain itu pada penelitian ini didapatkan bahwa semua subyek obesitas memiliki usia menarche yang normal. Hal ini dapat dijelaskan bahwa penyebab obesitas multifaktorial, dan lebih dipengaruhi oleh perilaku dan gaya hidup. ${ }^{20}$

Dari analisis bivariat antara usia menarche subyek dengan usia menarche keluarga menunjukkan bahwa terdapat hubungan yang bermakna. Hal ini sejalan dengan penelitian yang dilakukan oleh Towney yang menunjukkan bahwa usia menarche keluarga merupakan prediktor usia menarche keluarga putri. ${ }^{21}$

Dalam penelitian ini terdapat variabel perancu yang mempengaruhi obesitas. Berdasarkan analisis bivariat antara variabel perancu dengan status gizi didapatkan bahwa aktivitas fisik menunjukkan hubungan yang secara statistik bermakna, selain itu ditunjang dengan analisis multivariat yang menunjukkan bahwa aktivitas fisik merupakan variabel perancu yang paling berhubungan dengan status gizi. Hal ini sesuai dengan penelitian yang dilakukan oleh Diya Arofah di SMA N 5 Semarang yang menunjukkan bahwa terdapat hubungan yang bermakna antara aktivitas fisik dan obesitas. ${ }^{22}$ Penurunan aktivitas fisik akan berdampak terhadap pengeluaran energi di dalam tubuh yang sehingga terjadi keseimbangan energi postif. ${ }^{5}$

Beberapa penelitian pada anak-anak dan remaja dengan aktivitas fisik yang ringan memiliki IMT, simpanan lemak dan kejadian obesitas yang tinggi. ${ }^{23,24}$ Pada analisis univariat didapatkan bahwa $97,2 \%$ subyek memiliki tingkat aktivitas

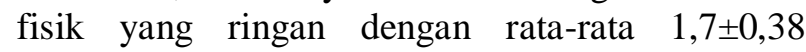
MET/hari. Sebagian besar subyek hanya melakukan olah raga saat jam pelajaran olah raga, selama 2 jam pelajaran selama seminggu.
Aktivitas sehari-hari yang sering dilakukan subyek antara lain menonton televisi, mengerjakan pekerjaan rumah, membaca buku dan bermain komputer. Pada hasil penelitian juga didapatkan bahwa sebanyak $2,8 \%$ subyek memiliki tingkat aktifitas fisik yang sedang. Data tersebut dapat dijelaskan karena sebagian subyek melakukan olah raga secara rutin dengan intensitas sedang selama 3 hari berturut-turut.

Hubungan antara variabel perancu yang terdiri dari asupan makan (energi, protein dan lemak) tidak menunjukkan hubungan yang bermakna dengan status gizi. Asupan energi subyek sebagian besar $(39,4 \%)$ berkategori kurang dari dengan rata-rata asupan sebesar 2260,6 $\pm 696,6 \mathrm{kkal} / \mathrm{hari}$. Asupan protein subyek sebagian besar $(74,6 \%)$ berkategori lebih dari asupan rata-

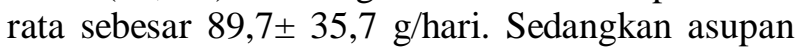
lemak subyek sebagian besar $83,1 \%$ dengan ratarata $111,3 \pm 42,4 \mathrm{~g} /$ hari. Dari Hasil penelitian ini menunjukkan bahwa sebagian besar subyek memiliki asupan energi, lemak dan protein yang tidak seimbang dari kebutuhan gizi remaja. Hal ini dapat terjadi karena pola diet dan presepsi body image remaja yang dapat mempengaruhi asupan makan yang tidak seimbang. Hal ini ditunjang dengan penelitian yang dilakukan oleh Cheung di Hongkong, yang menunjukkan bahwa terdapat hubungan pengaturan berat badan terhadap persepsi body image remaja melalui pembatasan asupan kalori. ${ }^{25}$ Selain itu pada penelitian oleh Nur Syuhada Zofiran di Malaysia menunjukkan bahwa terdapat hubungan perilaku makan dengan body image melaui emotional eating dimana remaja cenderung membenci dan mengurangi asupan makanan untuk mencapai bentuk tubuh yang mereka inginkan. ${ }^{26}$

\section{KETERBATASAN PENELITIAN}

Pada penelitian ini masih terdapat keterbatasan dalam pemilihan subyek penelitian dimana penelitian hanya dilakukan pada satu sekolah di kota Semarang. Selain itu adanya kelemahan dalam pengumpulan data menggunakan FFQ (Food Frequency Questionnaire) yaitu data dikumpulkan secara retrospektif selama sebulan terakhir, sehingga sangat tergantung pada daya ingat dan ketrampilan responden dalam menggambarkan frekuensi dan porsi makanan yang dikonsumsi.

\section{SIMPULAN}

Sebanyak $14,1 \%$ subyek termasuk dalam kategori obesitas. Rata-rata usia menarche subyek 
$12,1 \pm 1,3$ tahun dan sebanyak $2,8 \%$ berkategori dini ( $<10$ tahun). Tidak terdapat hubungan antara usia menarche dengan obesitas. Namun, didapatkan hubungan antara aktivitas fisik dengan kejadian obesitas melalui parameter IMT/U.

\section{SARAN}

Konsumsi asupan energi, protein dan lemak yang seimbang sangatlah dianjurkan untuk perkembangan remaja, baik secara kualitas dan kuantitas untuk mencapai pertumbuhan yang optimal. Selain itu, perlu adanya penyuluhan tentang pentingnya melakukan aktivitas fisik dan oleh pihak sekolah untuk mencegah terjadinya masalah kesehatan pada periode umur selanjutnya. Untuk penelitian lebih lanjut, disarankan untuk melakukan pengambilan sampel pada beberapa sekolah.

\section{DAFTAR PUSTAKA}

1. WHO Technical Report Series. Obesity : Preventing and Managing The Global Epidemic. Genewa : 2000.p. 6-7, 102-12.

2. Antipatis VJ, Gilli TP. Obesity as a Global Problem. In: Bjontrop P. International Textbook of Obesity. New York: John Wiley and Sons; 2001.p. 3-5.

3. Bandini L, Flynn A, Scampini R. Overnutrition. In : Nutrition and Metabolism. The Nutrition Society: 2010.p. 360-68.

4. Smith JC. Understanding Children Obesity. Missisipi : University Press of Missisipi; 1999.p. 33-37, 60-4.

5. Groft LJ, Wadsorth T. Advanced Nutrition and Human Metabolism. Belmount: Thompson \& Wadsworth; 1999.p.132-33.

6. Wiknjosastro, Hanifa. Ilmu Kandungan. Jakarta : Yayasan Bina Pustaka Sarwono Prawiroharjo; 2005.p.103-27

7. Rahmawati NT, Janatin H. Secular Changes in Body Size and Menarche Age of Javanese Adolescent in Yogyakarta. Berkala Ilmu Kedokteran: 2005 ;4: 171-6.

8. Stang J. Nutrition in Adolescent. In : Mahan LK, Escott-Stump S. Krause's Food, Nutrition, and Diet Therapy. $12^{\text {th }}$ edition. Philadelphia: Saunders; 2008. p. 248 .

9. Kretchmer N. Developmental Nutrition. Bacon : 1997.p. 457-92.

10. Laitein J, Power C, Jarvelin MR. Family Social Class, Maternal Body Mass Index, Childhood Body Mass Index and Age at Menarche as A Predictors of Adult Obesity. Am J Clin Nutr [serial online] 2001 [cited March 30 2012]; 74: 287-94. Available from URL: HIPERLINK http://www.ajcn.org

11. Berenjy S, Hanaci P. Relation of Obesity and Menarche Aged among Adolescent Student.
Journal of Family and Reproductive Health. [serial online] 2008 [cited March 2 2012]; vol 2 (4): 1736. Available from URL: HIPERLINK http://journals.tums.ac.ir/

12. Badan Litbang Kesehatan Departemen Kesehatan RI. Status Gizi Penduduk Dewasa (15 tahun keatas) di Indonesia. Riset Kesehatan Dasar (RISKESDAS) 2007. http://www.depkes.go.id, 5 Maret 2012.

13. Badan Litbang Kesehatan Departemen Kesehatan RI. Status Gizi Penduduk Remaja 16-18 Tahun di Indonesia. Riset Kesehatan Dasar (RISKESDAS) 2010. http://www.depkes.go.id, 1 Maret 2012.

14. Mahdiah, Hadi H, Susetyowati. Prevalensi Obesitas dan Konsumsi Fast Food dengan Kejadian Obesitas Remaja SLTP Kota dan Desa di Daerah Istimewa Yogyakarta. Jurnal Gizi Klinik Indonesia [serial online] 2004 [cited May 15 2012]; vol 1 (2). Available from URL: HIPERLINK http://www.ijen.org

15. Badan Litbang Kesehatan Departemen Kesehatan RI. Status Gizi Penduduk Dewasa (15 tahun keatas) di Jawa Tengah. Riset Kesehatan Dasar (RISKESDAS) Provinsi Jawa Tengah 2007. http://www.depkes.go.id, 5 Maret 2012.

16. Wiknjosastro, Hanifa. Ilmu Kandungan. Jakarta : Yayasan Bina Pustaka Sarwono Prawiroharjo; 2005.p.103-27

17. Ainsworth BE, et al. Compendium of Physical Activities: An Update of Activity Codes and MET Intensities. Medicine and Science in Sports and Exercise. [serial online] 2000 [cited 2012 June 25] 32 : 498-516. Available from URL HIPERLINK http://www.acsm.org

18. Supariasa IDN, Bakri B, Fajar I. Penilaian Status Gizi. Jakarta: Penerbit Buku Kedokteran EGC; 2002.p.106-14.

19. Kim JY, et al. The Relation of menarcheal Age to Anthropometric profiles in Korean Girls. J Korean Med Sci. [serial online] 2010 [cited 2012 September 10]; 25: 1405-10. Available from URL: HIPERLINK http://jkms.org

20. Mortensen LH, Siegler IC, Barefoot JC, Grønbæk M, Sørensen TIA. Prospective Association between Sedentary Behaviour and BMI in Midlife. International $\mathrm{J}$ of Obesity [serial online] 2006 [cited 2012 may 4];14:1462-71. Available from URL: HIPERLINK http://nature.com/ijo

21. Towney B, et al. Heritability of age at menarche in girls from the Fels Longitudinal Study. Am J Phys Anthropol [serial online] 2005 [cited 2012 August 17] ;Sep;128(1):210-9. Available from URL: HIPERLINK http://www.ncbi.nlm.nih.gov/pubmed/15779076

22. Diya A, Hertanto WS. Konsumsi Soft Drink Sebagai Faktor Risiko Terjadinya Obesitas pada Remaja Usia 15-17 tahun. Jurnal Media Medika Muda. 2010 ; Edisi Januari - Juli (4).p. 55-8.

23. Brug J, Lien N, Klepp K, Lenthe JF. Exploring Overweight, Obesity and Their Behavioural 
Correlates Among Children and Adolescents: Results from The Healthpromotion Through Obesity Prevention Across Europe Project. Public Health Nutrition [serial online] 2010 [cited 2012 April 17]; 14: 1676-9.

Available from URL: HIPERLINK http://journals.cambridge.org/

24. Ball EJ, O’Connor J, Abbott R, et al. Total Energy Expenditure, Bodyfatness, and Physical Activity in Children Aged 6-9 y. Am J Clin Nutr. [serial online] 2001[cited 2012 April 17];74:524-8. 896903. Available from URL: HIPERLINK http://www.ajen.org

25. Cheung PCH, Ip LSP, Lam ST, Bibby H. A Study on Body Weight Perception and Weight Control Behaviour among Adolescent in Hongkong. Hongkong Med J. 2007 [cited 2012 October 10]; 13: 16-21. Available from URL: HIPERLINK http://hkmj.org

26. Nur Syuhada ZMJ, Kartini I, Siti SSB, Ajau D. The Relationship Between Eating Behaviours, Body Image and BMI Status among Adolescence Age 13 to 17 years in Meru, Klang, Malaysia. Am J Food Nutr. 2011 [cited 2012 October 10];1(4): 185-92. Available from URL: HIPERLINK http://www.scihub.org/AJFN 